\title{
SEROPREVALENCIA DEL VIRUS DE LA DIARREA VIRAL BOVINA EN GANADO LECHERO DE CRIANZA INTENSIVA DEL VALLE DE LIMA
}

\author{
Renzo Aguilar S. ${ }^{1}$, Alfredo Benito Z. ${ }^{2}$ y Hermelinda Rivera G. ${ }^{2,3}$
}

\section{Abstract}

The prevalence of bovine viral diarrhea virus (BVDV) was determined in 12 dairy herds of the Lima valley. Blood samples were taken in 311 female cattle older than 6 months of age for the detection of antibodies against BVDV by viral neutralization test. The herds did not have history of vaccination against bovine viral diarrhea disease. The prevalence of BVDV was $56.0 \pm 5.5 \%$ (174/311) and the titers of antibodies against BVDV ranged from 2 to $>256$. Five out of the 12 herds did not have seropositive animals. The results indicated that the BVDV was widely distributed in dairy herds of Lima valley; although viral prevalence is low and some herds are free of the disease.

Key words: bovine viral diarrhea virus, bovine, dairy herd, antibody, prevalence

\section{ResuMEN}

El objetivo del presente estudio fue determinar la prevalencia del virus de la diarrea viral bovina (VDVB) en bovinos productores de leche bajo crianza intensiva en el valle de Lima. Se colectaron muestras de sangre de bovinos hembras mayores a 6 meses $(n=311)$ procedentes de 12 hatos sin antecedentes de vacunación contra la enfermedad de la diarrea viral bovina, para la detección de anticuerpos mediante la prueba de neutralización viral. El $56.0 \pm 5.5 \%$ (174/311) de las muestras presentaron anticuerpos contra el VDVB con títulos entre 2 a $>256$. Cinco de los 12 hatos muestreados no tuvieron animales serorreactores. Los resultados indicaron que el VDVB estaba difundido en el valle de Lima, aunque se encuentran hatos libres de la infección viral o con una prevalencia viral muy baja.

Palabras clave: virus de la diarrea viral bovina, bovino lechero, hato, anticuerpo, prevalencia

\footnotetext{
${ }^{1}$ Práctica privada

${ }^{2}$ Laboratorio de Microbiología y Parasitología Veterinaria, FMV-UNMSM

${ }^{3}$ E-mail: hriverag2005@yahoo.es
} 


\section{INTRODUCCIÓN}

El virus de la diarrea viral bovina (VDVB) es uno de los patógenos de distribución mundial que afecta a los rumiantes domésticos y silvestres causando pérdidas económicas debido a las infecciones transplacentarias y a su asociación con otros patógenos del tracto respiratorio y digestivo (Houe, 2003). El VDVB, conjuntamente con los virus de la peste porcina clásica y de la enfermedad de la frontera, son miembros del género pestivirus de la familia Flaviviridae (Collett et al., 1989; Ridpath, 2003). Los pestivirus se replican en todas las células del hospedador, pero preferentemente en células del sistema linforeticular y células epiteliales, por lo que son considerados inmunosupresores.

La infección viral se presenta en forma aguda pero con manifestaciones leves o subclínicas, con un corto periodo de replicación viral en los tejidos y eliminación viral, seguido de una completa recuperación debido a una sólida respuesta inmunitaria humoral y celular. Si el animal está gestando, el virus atraviesa la placenta y puede ocasionar un conjunto de fetopatías que va desde una reabsorción embrionaria, aborto o malformación congénita, hasta el nacimiento de terneros infectados en forma persistente como resultado de la infección fetal entre 40 a 120 días de la gestación. El ternero que nace infectado es inmunotolerante al virus, $y$ por lo tanto, portador y principal diseminador del virus. Se considera que un solo animal portador puede infectar al $90 \%$ de los animales del hato (Houe, 1995; Schreiber et al., 1999).

Estudios de seroprevalencia del VDVB realizados en bovinos y en camélidos sudamericanos muestran que el virus está distribuido en el país con prevalencias que varían de cero a mayores de $90 \%$. Incluso, se han detectado animales portadores del virus en hatos con programas de vacunación (Chacón et al., 2002); así mismo, se ha identificado al virus como uno de los principales agentes causantes de aborto (Rivera, 2001). La falta de control de la DVB en el valle de Lima, la existencia de animales portadores y el tránsito irrestricto del ganado podrían ser algunas de las razones de la amplia distribución del virus en el país.

Los estudios de prevalencia de un agente infeccioso bacteriano o viral es importante porque sirve de base para otros estudios epidemiológicos y para efectuar o diseñar medidas de control, por lo que el objetivo del presente estudio fue conocer la prevalencia del VDVB en hatos de bovinos productores de leche sin historia de vacunación, ubicados en el valle de Lima.

\section{Materiales y Métodos}

\section{Lugar de estudio}

El presente estudio se realizó en doce hatos lecheros de crianza intensiva del valle de Lima, ubicados en las zonas de Huaral (2), Huacho (1), Chancay (2), Carabayllo (2), Puente Piedra (2), Lurín (1) y Cañete (2). Estos fueron agrupados según su ubicación geográfica en zona sur, centro y norte. Los hatos no contaban con un programa de vacunación contra la diarrea viral bovina desde por lo menos cinco años atrás.

\section{Animales y muestras}

Se muestrearon bovinos hembras mayores de seis meses, sin tomar en cuenta su estado productivo o reproductivo. Las muestras de sangre se obtuvieron por punción de la vena yugular, utilizando el sistema de vacutainers. Los sueros resultante fueron trasvasados a viales y almacenados a $-20{ }^{\circ} \mathrm{C}$ en el Laboratorio de Virología de la Facultad de Medicina Veterinaria (FMV), Universidad Nacional Mayor de San Marcos (UNMSM). 
Cuadro 1. Número de animales muestreados por hato lechero en el valle de Lima, para la determinación de la seroprevalencia de la diarrea viral bovina

\begin{tabular}{ccc}
\hline Establo & Animales (n) & Muestra (n) \\
\hline A & 300 & 22 \\
B & 250 & 18 \\
C & 450 & 33 \\
D & 75 & 5 \\
E & 780 & 56 \\
F & 140 & 10 \\
G & 451 & 33 \\
H & 230 & 17 \\
I & 325 & 24 \\
J & 220 & 16 \\
K & 586 & 42 \\
L & 480 & 35 \\
\hline Total & 4,287 & 311 \\
\hline
\end{tabular}

\section{Tamaño de muestra}

El tamaño mínimo de muestra fue de 310 y se obtuvo por el método no paramétrico de muestreo al azar simple, considerándose una prevalencia de $72 \%$ (Contreras et al., 2000), un nivel de confianza de $95 \%$ y una precisión del 5\% (Daniel, 1996). El número mínimo de muestras fue estratificado de acuerdo a la población de cada establo (Cuadro 1).

\section{Prueba de neutralización viral}

La detección y titulación de los anticuerpos contra el VDVB se realizó mediante la prueba de neutralización viral, según el protocolo disponible en el Laboratorio de Virología y descrita previamente (Alvarez et al., 2002, Rivera et al., 2002).

\section{Material biológico}

Se utilizó cultivo secundario de células de cornete nasal de feto bovino (CNB) libres de VDVB como sistema indicador de la prue- ba de neutralización viral, preparados en el Laboratorio de Virología de la FMVUNMSM. Se emplearon medios de cultivos consistentes en 50\% de MEM y Leibovitz15 , con $1 \%$ de antibióticos y antimicóticos comerciales (Sigma, EEUU).

El antígeno usado en la prueba de neutralización viral fue la cepa Singer, prototipo del biotipo CP, genotipo I del VDVB con un título de $10^{-5} \mathrm{DI}_{50} \mathrm{cc} / 50 \mu \mathrm{l}$.

Un suero fue considerado positivo a anticuerpos contra el VDVB al neutralizar 75 a $100 \%$ de la capacidad infectante del virus en cultivo celular, manifestado por ausencia del efecto citopático, y fue considerado negativo si no neutraliza la capacidad infectante del virus, observándose el efecto citopático.

La prevalencia fue determinada y expresada en forma porcentual y con un intervalo de confianza de $95 \%$. 
Cuadro 2. Seroprevalencia del virus de la diarrea viral bovina en bovinos lecheros de 12 establos del valle de Lima (2002)

\begin{tabular}{cccc}
\hline \multirow{2}{*}{ Establo } & Animales muestreados & \multicolumn{2}{c}{ Animales con anticuerpos contra VDVB } \\
\cline { 3 - 4 } & $(\mathrm{n})$ & $\mathrm{N}^{\mathrm{o}}$ & $\%$ \\
\hline A & 22 & 0 & 0 \\
B & 18 & 0 & 0 \\
C & 33 & 4 & 12.1 \\
D & 5 & 0 & 0 \\
E & 56 & 56 & 100.0 \\
F & 10 & 0 & 0 \\
G & 33 & 15 & 0 \\
H & 17 & 0 & 33.3 \\
I & 24 & 8 & 100.0 \\
J & 16 & 16 & 100.0 \\
K & 42 & 42 & 94.3 \\
L & 35 & 33 & $56.0 \pm 5.5$ \\
\hline Total & 311 & 174 & \\
\hline
\end{tabular}

\section{Resultados}

Siete de los 12 establos muestreados tuvieron animales serorreactores al VDVB, resultando una seroprevalencia de $56.0 \pm$ $5.5 \%(174 / 311)$ (Cuadro 2).

El virus tuvo una mayor prevalencia en los hatos de la zona sur (Cuadro 3). Así mismo, los animales mayores de 2 años tuvieron una seroprevalencia de $60.5 \pm 6.0(156 / 258)$, mientras que en los animales menores de 2 años fue de $34.0 \pm 12.8$ (18/53). Los títulos de anticuerpos neutralizantes estuvieron en un rango de 2 a >256 (Cuadro 4).

Las informaciones obtenidas de los propietarios y datos de los registros sanitarios no evidenciaron signos de la enfermedad clínica de la DVB, pese a que se registraron problemas reproductivos y respiratorios.

\section{Discusión}

La detección de anticuerpos contra el VDVB en el $56 \%$ de la población bovina de hatos sin historia de vacunación indica una evidente exposición de los animales al virus de campo. Los resultados también indican que si bien el virus estuvo distribuido en la población bovina en las tres zonas del valle de Lima, hubieron cinco hatos con ausencia de animales serorreactores (Cuadro 2).

La infección fue aparentemente de tipo subclínica, pero con posible impacto en la producción al ocasionar fallas reproductivas e infecciones respiratorias como un agente secundario (Campbell, 2004). Un animal con infección aguda o subclínica presenta viremia entre el $4^{\circ}$ al $5^{\circ}$ día de la infección y puede persistir por más de 15 días eliminando el virus en las secreciones y excreciones; consti- 
Cuadro 3. SeroprevaIencia de la diarrea viral bovina en el valle de Lima, según la ubicación geográfica de los establos (2002)

\begin{tabular}{lccc}
\hline & Animales & \multicolumn{2}{c}{ Animales con anticuerpos contra } \\
Zuestreados & $(\mathrm{n})$ & $\mathrm{n}$ & $\%$ \\
\cline { 3 - 4 } & 134 & 60 & $44.8 \pm 8.4$ \\
\hline Norte & 100 & 39 & $39.0 \pm 9.6$ \\
Centro & 77 & 75 & $97.4 \pm 3.6$ \\
Sur & 311 & 174 & $56.0 \pm 5.5$ \\
\hline \multicolumn{1}{c}{ Total } & & & \\
\hline
\end{tabular}

Cuadro 4. Distribución de los títulos de anticuerpos contra el virus de la diarrea viral bovina, según la ubicación geográfica de los establos (2002)

\begin{tabular}{lcccc}
\hline \multirow{2}{*}{ Zona } & Animales & \multicolumn{3}{c}{ Inversa de la dilución del suero } \\
\cline { 3 - 5 } & $(\mathrm{n})$ & $2-8$ & $16-32$ & $128->256$ \\
\hline Norte & 74 & 4 & 50 & 6 \\
Centro & 61 & 0 & 22 & 17 \\
Sur & 2 & 9 & 49 & 17 \\
\hline \multicolumn{1}{c}{ Total } & 137 & 13 & 121 & 40 \\
\hline
\end{tabular}

tuyendo una fuente de infección para el resto de animales susceptibles (Baker, 1995; Houe, 1999). El virus tiene mayor oportunidad para infectar a los animales susceptibles en poblaciones numerosas y de crianza intensiva, situación que podría estar ocurriendo en los hatos donde se detectaron altas prevalencias de la infección.

En estudios previos, Rivera et al. (2002) reportaron que el $21 \%$ (6/29) de fetos abortados tenían el antígeno del VDVB, y que el $69 \%$ de las vacas que abortaron tuvieron anticuerpos contra este virus. Si bien esta información no implica únicamente al VDVB como causante de los abortos, ya que existen otros agentes en el medio como Neospora caninum, sugiere que el VDVB puede ser un componente del complejo reproductivo y respiratorio (Brownlie, 1991) en algunos de los hatos en estudio. La ausencia de infec- ción viral en algunos hatos podría deberse al sistema de bioseguridad empleado, donde mantienen el hato cerrado, y por lo tanto, con menor oportunidad de ingreso del virus; sin embargo, también podría deberse a que el virus haya tenido una baja prevalencia.

En el presente estudio se encontró una mayor presencia del virus en los establos de la zona sur y en aquellos con mayor población de animales (cuadros 2 y 3); indicando que el virus tuvo mayor oportunidad de difundirse dentro del hato, aunque también puede ser indicativo de la existencia de animales portadores del virus. Se menciona que un hato con prevalencias entre 40 a $>70 \%$ tiene grandes posibilidades de tener al menos un animal portador (Houe, 1995; Schreiber et al., 1999; Houe, 2003). Estos conceptos han sido demostrados en hatos de crianza intensiva y semi extensiva de cuencas lecheras como el 
valle de Lima, el Mantaro y Arequipa (Chacón et al., 2002; Morales et al., 2002; Rivera et al., 2002).

En relación a la prevalencia viral por edad de los animales muestreados se determinó que el virus fue más prevalente en los animales mayores a 2 años, probablemente debido a que estos animales tuvieron mayor oportunidad de infección (Fredriksen et al., 1999). Los anticuerpos neutralizantes inducidos por virus de campo permanecen por mucho tiempo o por toda la vida del animal (Rufenatch et al., 2000).

\section{Literatura Citada}

1. Alvarez, S.; H. Rivera; D. Pezo; W. García. 2002. Detección de anticuerpos contra pestivirus en rumiantes de una comunidad campesina de la provincia de Canchis, Cusco. Rev. Inv. Vet, Perú 13: 46-51.

2. Baker, J. 1995. The clinical manifestation of Bovine Viral Diarrhea infection in BVD virus. Vet. Clin. North Am. Food Anim. Practice 11: 425-445.

3. Brownlie, J., 1991. The pathways for bovine virus diarrhea virus biotypes in the pathogenesis of disease. Arch. Virol. 3: 79-96.

4. Campbell, J.R. 2004. Effect of bovine viral diarrhea virus in the feedlot. Vet. Clin. Food Anim. Practice 20: 39-50.

5. Chacón, J.; A. Benito; H. Rivera. 2002. Detección de animales portadores del virus de la diarrea viral bovina en un establo vacunado y en otro sin vacunar del valle de Lima. Rev. Acad. Per. Cienc. Vet. 3: 14-23.

6. Collett, M.S; V.Moening; M.C. Horzinek. 1989. Recent advances in pestivirus research. J. Gen. Virol. 70: 253-266.

7. Contreras, G.; K. Ståhl; C. Arana; H. Rivera. 2000. Anticuerpos contra el virus de la diarrea viral bovina en muestras de leche de bovinos del valle del Mantaro. Rev. Inv. Vet., Perú 11: 58-65.
8. Daniel, W.W. 1995. Bioestadística: base para el análisis de las ciencias de la salud. $5^{a}$ ed. p 269-280. Ed. Limusa. México DF.

9. Fredriksen, B.; T. Sandvik; T. Loken; S.A. Odegaard. 1999. Level and duration of serum antibodies in cattle infected experimentally and naturally with bovine virus diarrhea virus. Vet. Rec. 144: 111-114.

10. Houe, H. 1995. Epidemiology of bovine viral diarrhea virus. Vet. Clin. North Am. Food Anim. Practice 11: 521-547.

11. Houe, H. 1999. Epidemiological features and economical importance of bovine virus diarrhea virus (BVDV) infections. Vet. Microbiol. 64: 89-107.

12. Houe, H. 2003. Economic impact of BVDV infection in dairies. Biologicals 31: 137-143.

13. Morales, S.C.; A. Benito; H. Rivera. 2002. Terneros persistentemente infectados con el virus de la diarrea viral bovina en dos hatos lecheros de la provincia de Arequipa. Rev. Acad. Per. Cienc. Vet. 3: 8-13.

14. Ridpath, J. 2003. BVDV genotypes and biotypes: practical implications for diagnosis and control. Biologicals 31: 127-131.

15. Rivera, H. 2001. Etiología infecciosa del aborto bovino. Rev. Inv. Vet., Perú Supl. 1: 95-99.

16. Rivera, H.; K. Huamán; A. Benito; A. Díaz; C. Arana. 2002. Prevalencia del virus de la diarrea viral bovina y animales portadores del virus en un hato lechero del valle del Mantaro. Rev. Acad. Per. Cienc. Vet. 3: 1-7.

17. Rufenatch, J.; P. Schaller; L. Audige; M. Strasser; E. Peterhans. 2000. Prevalence of cattle infected with bovine viral diarrhea virus in Switzerland. Vet. Rec. 147: 413-417.

18. Schreiber, P.; E. Dubois; F. Dreze; N. Lacroix; B. Limbourg; P. Coppe. 1999. Prevalence of bovine virus diarrhea virus infection in Belgian White Blue cattle in Southern Belgium. Vet. Quart. 21: 28-32. 